\title{
Four performances for the New Acropolis Museum
}

When the politics of space enter the becoming of place

\section{Sofia Paisiou, Fribourg}

\section{Introduction}

\begin{abstract}
«We make and constantly remake the spaces and places and identities through which we live our lives [...]. All these involve the co-constitution of spaces and identities where the spaces can be thought of as geometries (in the most informal sense of that word) of a variety of forms of power» (MASSEY 1999: 290).
\end{abstract}

In this quotation, MASSEY (1999) introduces the importance of places as they «arrange» our personal spaces, our social and public spheres, and our everyday life; to a great extent spatiality determines who we are. Thus it is very important to understand how places are made, or as DeLANDA argues (DunNE \& DoeTsch 2006: 208) to locate the dynamic processes of the genesis of form (MASSEY's «geometries») in a force field of different tendencies.

According to VAN WeZemael (2010a) contemporary literature in urban geography and planning reflects the production of places as a complex layering of multiple networks (Amin 2004; HeALEY 2007; THRIFT 2000). However, interdisciplinary work across these disciplines is noticeably lacking (HILLIER 2010). In this respect, LAW and URRY (2004) suggest that social and physical changes need to be parallelled by changes in the methods of social inquiry, which means by the way we know (epistemology) and by our concepts of reality (ontology).

Conceptually this article is based on assemblage theory of social complexity (DELANDA 2006). The study is a trajectory shaped by the four competitions for the New Acropolis Museum (NAM) in Athens in 1976, 1978,1989 and 2000 . Following actor network theory (LATOuR 2005) and its development as «assemblage method» by LAw (2004), this study traces social movements, political narratives, socio-technical collectives and frameworks and aims to contribute to a better understanding of reality in place making by working towards a perspective that recognizes the complexity in place making processes, such as the architectural competitions, as a property of reality and not as a property of humans interpreting reality (DeLanda 2010:251; VAN WeZemael 2010b).

The specific case of the NAM was chosen for the following reasons:
Firstly, from the point of view of global culture and its symbolism. According to YALOURI (2001: 192), symbols like Acropolis condense understandings about Greek identity, but when Acropolis Hill became a part of the UNESCO World Heritage List in 1987 (FousEKI 2006), the creation of NAM opened up an international discourse of repatriation of the Parthenon Marbles from the British museum. The repatriation claim has gradually shifted a legal-international argument to a museological-local one, regarding the appropriate way of displaying the monuments «real aesthetics» in their «authentic context» (Fouseki 2006). This travel from one «site» to the other, according to LATour (2005: 176 ), must be traced so that «the full cost of relation, displacement and information» is revealed. In the following parts this study brings the attention back to the local and will describe the arrays of connections, along which competitions as vehicles (e.g. carrying types of documents, inscriptions) (LATOUR 2005: 176-177) travel to the site to introduce «the global» into the densely packed, everyday life of Athens.

Secondly, the creation of the NAM has always been associated with the competition process. Competitions are «couplings between diverse fields of society» (KoHoutek 2005: 125). More precisely, «the complex layering of multiple networks of the place making» enters the competition process in the form of various technologies of representation and communication: images, text, models, actors and their discourses. Competitions are platforms recombining various modes of knowledge, discursive arguments and materials of representation, and generate knowledge and innovation (PAisou et al. 2011; Volker 2010), while at the same time set out a trajectory from imagination towards realization (CHUPIN 2010).

Finally, what makes these competitions particularly interesting is that for thirty years they have acted as «regular» meeting points to provide answers to the question of how to bring the NAM into being. Every competition for the NAM acts as vehicle and opportunity to witness the gathering of various human and non-human actors and to follow their attempts to decipher and diffuse broader issues of culture, architecture, politics and economy. The four NAM competitions illustrate that decisions about place making can be performed in many different ways and highlight the fact that reality is made and enacted by producing different but coexisting and related objects (MoL 1999) or, as LAw (2004: 21) states: 
«Realities are being constructed. Not by people. But in the practices made possible by networks of elements that make up the inscription device.»

\section{What were the choices that «constructed» the NAM?}

As stated previously, design competitions are gatherings where people and objects are folded together producing new urban possibilities concerning place making. To deal with their complex properties competitions are studied as inscription devices following the «assemblage method» (LAw 2004). An inscription device is mainly responsible for the manipulation of inscriptions and statements, a set of arrangements for converting relations from non trace to trace like form or a set of practices for shifting material modalities (LAw 2004).

Method assemblage enables us to deal with all the actors and the full complexity of the situation in an «assemblage» (LAw 2004). It should be used as a vocabulary for thinking about method, about the creativity and performativity of a continuous process of enacting and crafting necessary boundaries between presence, (what is here), manifested absence and otherness (what is absent but hidden, repressed or uninteresting) (LAw 2004). A competition is just such an inscription device, not only a platform but

«a process of bundling, of assembling where the elements put together are not fixed in shape and do not belong to a pregiven list, but they are constructed at least in part as they are entangled together» (LAw 2004: 122)

which outputs answers and architectural projects. It is a way of thinking and making sense (KREINER 2007; PAIsIou et al. 2011), of describing and making reality. Each competition, and all four, have shaped the landscape of choices for the creation of the place NAM, by creating realities (presence) and statements about the un-made realities (absence, otherness).

The following section unfolds the diversities of the four competitions in order to reveal the «productive differences» (DELANDA 2002: 61-64) capable of transition from the imaginary state to the state of creation. Since MoL (1999) and LAw (2004) argue that choices about realities lie within the various devices, the discussion presented here starts by opening the black boxes of the four competitions so as to trace the landscape of possibilities they introduce and the realities they have performed.

\subsection{The choice of site}

The physical site is important because it sets out the physical dimensions of future possibilities and is considered as the entry point to the force field of tendencies. In 1976, the Greek Prime Minister selected Makri- gianni as site, because it was a state property close to Acropolis, despite being small, awkward in shape, and containing the Weiler Building. The «top down» decisions about the site and the competition processes in 1976 and 1978 marked the start of the NAM but also lead the search from a technical and aesthetic point of view almost in a dead end (Kontaratos 1978). Addressing these difficulties the jury suggested «an ideas competition in two stages» and a prestudy for alternative locations (KonTARATOS 1978).

Thus, in 1989, for the third competition, three sites were put forward: Makrigianni, Dionissos and Koili. The competing architects could use one of these plots or all of them simultaneously. Despite SADAS (the National Association of Architects) suggestion that the alternative locations were more adequate for NAM creation (KonTARATOS 2010), and the fact that, in 2000 the site «shrunk» due to excavation by the Central Archeological Committee (KAS) (PANGalos \& MENDONI 2009), the winning award in the third and the fourth competition were located on Makrigianni (Ministry of Culture \& D.O.M.S. 1991:35-42; (b) (c)).

The return to Makrigianni site in 2000 raised many opponents (the «Citizen movement» composed of members of SADAS and others (FousEKI 2006; IOS 2002) but it was approved by both SADAS and KAS (IOS 2002) and supported by the state's implementation of a flexible legal framework that facilitated the creation of NAM (b: 8-9). Furthermore, its position at the centre of a network of urban strategies such as the metro and the «unification of archaeological sites of Athens» were added to the site's advantages (b).

In order to follow this bundle of changes, the next part presents the detailed analysis of the four competitions.

\subsection{The choice of the competition formats}

There are differences between how each of the four competitions was organised and how their procedures were standardised. The first two competitions in 1976 and 1978 were both governed by national laws (1). The initiator of the first national competition was the Ministry of Culture, but the original idea came from the former Prime Minister (K. KARAMANLIs, conservative), who was actively and personally involved in the organisation of the first competition (KonTARATOS 1978). Although two projects were selected as third and second prize winners in 1976 and 1978 respectively (Table 1), the competition did not lead towards a contract or realization. As KonTARATos (1978) states, this should not be considered as a failure or shortcoming of the competitors or the jury, since the final goal of a competition is not to find a «ready to use» solution but to select an architect who can successfully deal with the design problem. 


\begin{tabular}{|c|c|c|c|c|c|c|}
\hline Year & Type & Initiator & Winner & $\begin{array}{l}\text { Real- } \\
\text { ised }\end{array}$ & $\begin{array}{l}\text { Implemented } \\
\text { regulation }\end{array}$ & Relevant authority \\
\hline 1976 & $\begin{array}{l}\text { Competition of } \\
\text { the Acropolis } \\
\text { Museum } \\
\text { national, one } \\
\text { stage }\end{array}$ & $\begin{array}{l}\text { Ministry of } \\
\text { Culture }\end{array}$ & $\begin{array}{l}\text { Third prize: } \\
\text { M. Kandrevioto, } \\
\text { Prof. } \\
\text { Avgoustinos } \\
\text { architects }\end{array}$ & no & $\begin{array}{l}\text { F.E.K (1970): Peri } \\
\text { Egkriseos } \\
\text { prodigrafon } \\
\text { architektonikon d } \\
\text { iagonismon (1) }\end{array}$ & $\begin{array}{l}\text { Minister of } \\
\text { Coordination and } \\
\text { the Ministry of } \\
\text { Public Works }\end{array}$ \\
\hline 1978 & $\begin{array}{l}\text { Competition of } \\
\text { the Acropolis } \\
\text { Museum } \\
\text { national, one } \\
\text { stage }\end{array}$ & $\begin{array}{l}\text { Ministry of } \\
\text { Culture }\end{array}$ & $\begin{array}{l}\text { Second prize: } \\
\text { I. Liakatas } \\
\text { A. Pechlivanidou- } \\
\text { Liakata }\end{array}$ & no & $\begin{array}{l}\text { F.E.K (1970): Peri } \\
\text { Egkriseos } \\
\text { prodigrafon } \\
\text { architektonikon d } \\
\text { iagonismon (1) }\end{array}$ & $\begin{array}{l}\text { Minister of } \\
\text { Coordination and } \\
\text { the Ministry of } \\
\text { Public Works }\end{array}$ \\
\hline 1989 & $\begin{array}{l}\text { International } \\
\text { architectural } \\
\text { competition of } \\
\text { the New } \\
\text { Acropolis } \\
\text { Museum, } \\
\text { two stage ideas } \\
\text { competition }\end{array}$ & $\begin{array}{l}\text { Ministry of } \\
\text { Culture, } \\
\text { Directorate } \\
\text { of Museum } \\
\text { Studies }\end{array}$ & $\begin{array}{l}\text { First prize: } \\
\text { Prof. Nicoletti } \\
\text { L. Passarelli }\end{array}$ & no & $\begin{array}{l}\text { UNESCO-UIA } \\
\text { regulations }\end{array}$ & $\begin{array}{l}\text { International } \\
\text { Union of } \\
\text { Architects (UIA), } \\
\text { mandated by } \\
\text { UNESCO to } \\
\text { oversee inter- } \\
\text { national } \\
\text { architecture } \\
\text { competitions }\end{array}$ \\
\hline 2001 & $\begin{array}{l}\text { Competition for } \\
\text { the selection of } \\
\text { partner for the } \\
\text { architectural } \\
\text { structural, } \\
\text { electromechanical } \\
\text { design of the New } \\
\text { Acropolis } \\
\text { Museum, } \\
\text { two stage process }\end{array}$ & $\begin{array}{l}\text { OANMA } \\
\text { Organisation } \\
\text { for the } \\
\text { construction } \\
\text { of the New } \\
\text { Acropolis } \\
\text { Museum }\end{array}$ & $\begin{array}{l}\text { Bernard } \\
\text { Tschumi } \\
\text { Architects } \\
\text { AR.SY. } \\
\text { Architectural } \\
\text { cooperation } \\
\text { LTD } \\
\text { ADK Aronis- } \\
\text { Drettas-Karlaftis } \\
\text { consulting } \\
\text { engineers } \\
\text { MMB design } \\
\text { group S.A. }\end{array}$ & yes & $\begin{array}{l}\text { European } \\
\text { Directive } \\
\text { 92/50/EU (5) } \\
\text { governing public } \\
\text { works, implemen- } \\
\text { ted in the Greek } \\
\text { laws F.E.K (1998): } \\
\text { P.D.346 } \\
\text { Prosarmogi tis } \\
\text { ellinikis } \\
\text { Nomothesias gia } \\
\text { tis diosiefseis pros } \\
\text { tis diatajeis tis } \\
\text { odigias } 92 / 50 / \text { EOK } \\
\text { tis } 18 \text { Iouliou } 1992 \\
\text { (2) } \\
\text { F.E.K (1994): } \\
\text { Organisation for } \\
\text { the construction of } \\
\text { the New Acropolis } \\
\text { Museum N2260/94 } \\
\text { (3) } \\
\text { F.E.K (2000): } \\
\text { N2819/2000 Idrisi } \\
\text { eterias Olimpiako } \\
\text { xorio kai alles } \\
\text { diataxeis (4) }\end{array}$ & European Union \\
\hline
\end{tabular}

Tab. 1: NAM competition formats

Verschiedene NAM Wettbewerbsarten

Cadres relatifs au concours du NAM

Sources: Kontaratos 1978; Ministry of Culture \& D.O.M.S. 1991; OANMA 2001; F.E.K. 1970, F.E.K. 1998, F.E.K. 1994, F.E.K. 2000, EEC 1992 
In 1989, the Ministry of Culture initiated the third competition, a two-stage ideas competition as the jury of 1976 suggested. The chosen framework was the «Guide of International Competitions» as defined by the International Union of Architects (UIA-UNESCO) (see Table 1). The process was altered in two ways, concerning both the framework and the (architectural) audience. More precisely, the third competition's worldwide call laid down the conditions for the creation of the NAM to become a truly international event. This was an achievement of the former Minister of Culture (M. Mercouri, socialist), whose aim was to promote and spread Greek culture at home and abroad by prioritizing support for the NAM project, the conservation of the Acropolis monuments and the reunification of the Parthenon Marbles (the first request via UNESCO submitted in 1984 (Fouseki 2006). Thus, the choice of the framework was related to the political decision to link the return of the Marbles with the creation of the NAM. This automatically connected the NAM to the UIA-UNESCO framework and shifted the claim for the repatriation of the Marbles to a museological one (FousEKI 2006). It is owing to this mutual affiliation between the NAM and the Marbles (YALOURI 2001), that the realization of NAM, which until this time, was managed at a national level, could «find its place» in an international setting.

Finally, the fourth competition in 2000 was announced by a «private legal entity» overseen by the Greek Ministry of Culture: the Organisation for the creation of the New Acropolis Museum (OANMA, established in 1994 (3)). The framework in this case was given by the European Directive 92/50/EU (5) and the relevant Greek laws (2), (3), (4) (Table 1).

In summary, this part illustrates how competitions function as inscription devices, by collecting and setting the precise rules which express the economic and political «trends» of each period, such e.g. as entering EU, the recognition of Acropolis by UNESCO. In order to understand the trajectories of every one of these four competitions, not only as a general consequence of their period but as an active and constructive component of reality, we need to look at these procedures in more detail: what do the legal frameworks really do (trace the judging procedure), which people are involved and what are their final outcomes.

\subsection{Choosing a judging process for the NAM}

«Methodical procedures and meticulous note-keeping are necessary. Otherwise a day's work is lost» (LAw 2004: 30). According to LAW (2004), every inscription device produces traces. Similarly, there are systematic minutes of competition jury sessions and jury reports are also drawn up to summarise the decisions; note-keeping makes it possible to trace how decisions are made.
Following the previous two, the third competition was a typical case of reflective architectural judgment. The UIA framework enabled a discursive and reflective decision process (CHUPIN 2010), where the programme's criteria, i.e. for example the relation with the surroundings, the volumetric analysis, the exposition of Parthenon Marbles (a), (Ministry of Culture \& D.O.M.S. 1991), were redefined and acted as entry points to discuss the architectural qualities of the projects handed in, in both phases of the third competition. These transformations were the basis for negotiations about the best solution for the NAM.

In the case of the forth competition programme, there are many references to the current laws on public works, in particular the sections on required qualifications of competitors and the section detailing that the final decision in the second phase should reward offers presenting the greatest economic advantage (b). The minutes of the jury session do not reveal deliberations of actual decision-making; rather they introduce new technology - a black box - that «ranks» submissions according to a complicated system that weighs up the competitors and their qualifications. The final table «Check of economic data of the tenders» conceals all the discussions of the jury inside the main factor ab. In this way projects were transformed to offers where «the higher (numeric) value of ab defines the more advantageous one» (c).

Finally in order to illustrate the sproductive differences» between UIA and EU frameworks, or how competition rules are translated to architectural decisions and built outcomes, it would be valuable to consider the difference between an architectural competition and a tender and its relation to innovation, knowledge creation and architectural quality (Volker 2010). As Dubey (2005) states, although the two procedures have structural similarities, they also have differing historical trajectories and they pursue different aims: a competition tries to define what a NAM is, what it looks like; it is a quest for a means of expression in architectural language. On the other hand, a tender judges the best offer for an object that is already defined by the client or initiator (DUBEY 2005).

\subsection{The choice of protagonists}

A competition framework defines which people are involved in the process. The networks in the NAM competitions comprise three groups:

- experts, jurors, initiators;

- the architectural teams interested in participating and those who have accepted to;

- the public these processes are addressed to.

The composition of the jury is a crucial part of the procedure, especially for the quality of the (archi- 


\begin{tabular}{|l|l|l|}
\hline $\begin{array}{l}\text { Requested credentials for } \\
\text { the fourth NAM } \\
\text { competition }\end{array}$ & Formal & Actual \\
\hline Requested documents & $\begin{array}{l}\text { - official diplomas } \\
\text { - «professional level» } \\
\text { - official statement about bankruptcy } \\
\text { (Art. 30 (2), or Art. 29 (5)) } \\
\text { - official statement about the } \\
\text { organisation of the offices } \\
\text { - in case of cooperation between } \\
\text { agencies, the details and contracts } \\
\text { of this cooperation }\end{array}$ & $\begin{array}{l}\text { - biographical notes } \\
\text { (last 15 years) similar to NAM } \\
\text { (type, scale) (according to Art. } \\
\text { 27.2.b (2) or Art. 32.2.b (5)) } \\
\text { - eight different experts } \\
\text { - detailed description of the organisation } \\
\text { of the offices (according to } \\
\text { Art. 27.2.st (2) or Art. 32.2.f (5)) } \\
\text { - official statements of office quality } \\
\text { (according to Art. 29 (2) or Art. 33 (5)) }\end{array}$ \\
\hline Checked by & Assessment committee \\
\hline
\end{tabular}

Tab. 2: Requested credentials for the fourth NAM competition 2000

Angeforderte Berechtigungsnachweise für den vierten NAM Wettbewerb 2000

Certificats demandés pour le quatrième concours du NAM 2000

Source: OANMA 2000 (b)

tectural) assessment. A jury is «a very dense knot of mental, material, and discursive relational networks» (VAN WeZemael et al. 2011: 167). In the first national competition, the jury was made up of Greek architects (KonTARATos 1978). The jury for the third competition consisted of an international panel of architects, opening up the process to an interchange between different international architectural practices. $\mathrm{A}$ «technical committee», composed of Greek members, dealt with organising and preparing the phases (a).

In the final competition, the jury members were not as internationally diverse but they did come from a variety of different technical backgrounds. There were two versions of this jury: in the first half of the first phase (preselection), a «Procedural Committee», and in second half, the «Assessment Committee» made the decisions (b).

The work of the juries in the pre-selection phase is one of the points of the framework and programme that strongly influences and structures the possible futures revealed by the competitions. In the third competition the call was open to all architects approved by the UIA, opening up the process to international architectural practice in 26 countries (Ministry of Culture \& D.O.M.S. 1991) and simultaneously opening up the space of possible solutions.

During the first phase of the fourth competition, architects were requested to present their «formal» credentials to the «Procedural Committee». Then the «Assessment Committee» checked the «actual» credentials which ensured the selection of proper teams-partnerships for the second phase (see Table 2), taking account of an additional criterion, the «value of experience» calculated by combining $55 \%$ for architectural experience, $20 \%$ for engineering experience, $20 \%$ for electrical $/$ mechanical studies and $5 \%$ for the experts of the teams (b). This international call resulted in collaborations between Greek and foreign offices of big engineering firms and star architects (e.g. IsOZAKI, LIBESKIND, Tschumi).

Few participants from the third competition entered the last one. This is another way of considering these processes. The competition programme sets the focus and the priorities for the overall procedure. It is a statement about the competition's goals and architectural views. Thus, some architects were excluded on the basis of their credentials, but others, like the second placed winner in 1989 T. MPIRIs \& associates (MINISTRY OF Culture \& D.O.M.S. 1991) and T. PAPAGianis $\&$ associates, excluded themselves (IOS 2002), since the last competitions had focussed on finding partners rather than architectural solutions, as Fig. 1 illustrates.

Finally, every competition aimed at a different audience, as the final publications illustrate (Ministry of Culture \& D.O.M.S. 1991; OANMA 2001), providing a good summary of the points raised hereby. The third competition produced multiple traces and opened up the possible futures of the NAM, as is apparent by the differences between the types of solutions. A 300 -page publication in two languages, presenting all 438 submissions with comments from political figures and all the jurors, shows this competition's international ambition and that of its initiator, celebrating the 

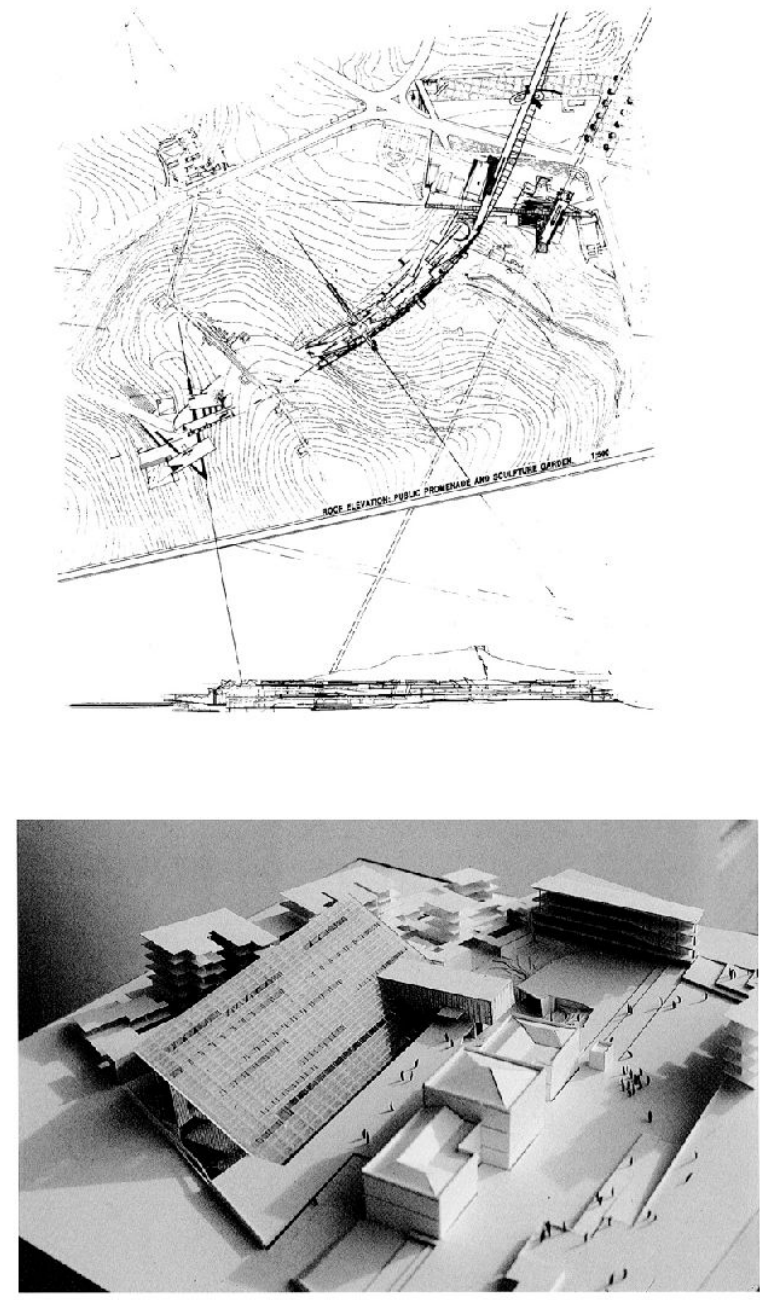
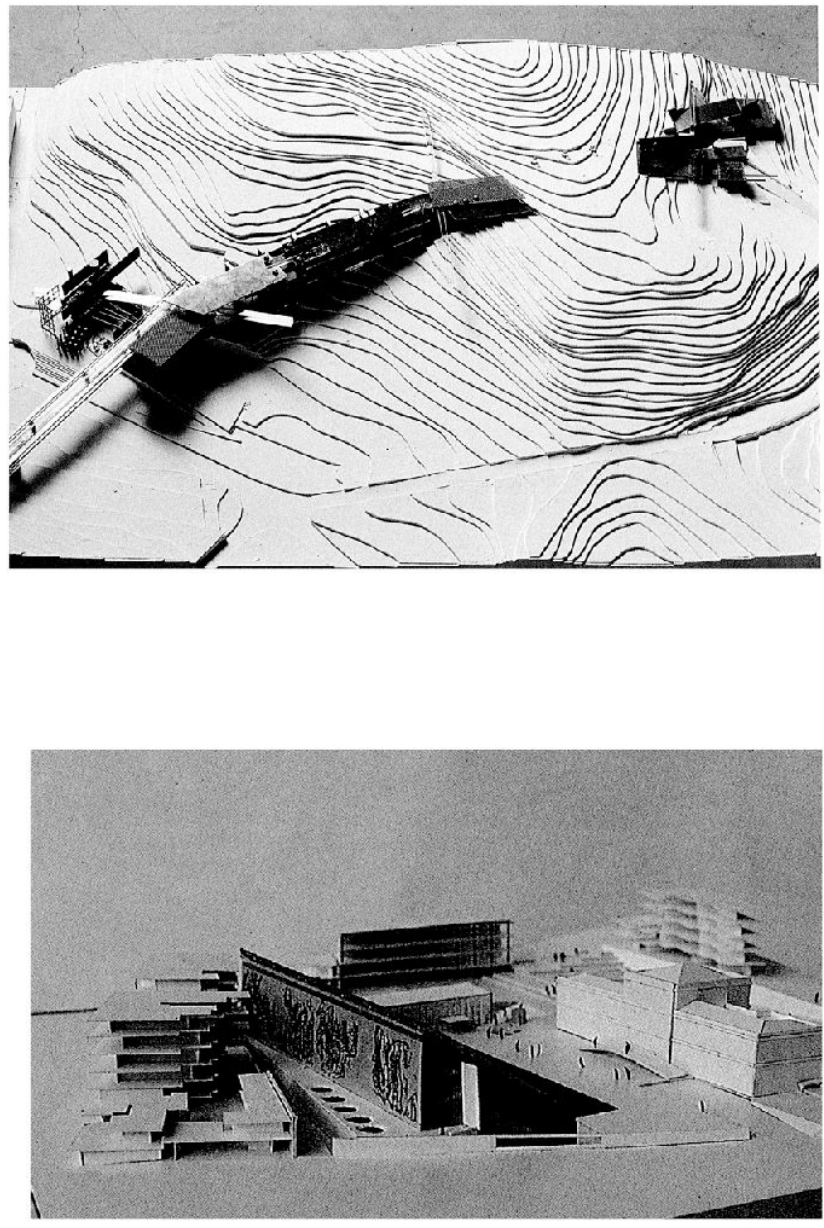

Fig. 1: Models and plans of the finalists of phase $\mathrm{A}$ of the third competition Modelle und Pläne der Finalisten der Phase A des dritten Wettbewerbs Maquettes et plans des finalistes de la phase $A$ du troisième concours Source: MinisTRY OF CULTURE \& D.O.M.S. 1991

diversity of international ideas. For the fourth competition, a 15-page publication was created, containing the same crucial section about the project's finalists, followed by one or two paragraphs from the jury's report. This 15-page publication highlighted the decision to judge every project according to an important blueprint that emphasised the relations between the project, the archaeological ruins and the Acropolis.

\subsection{Deciding beforehand: «reality is this way»}

According to MoL (1999: 80), inscription devices «shift the site of the decision elsewhere». The final decision on the NAM was not taken on the 21st October 2001; on this date the details of the decisions were negotiated. The decisive moments were displaced to other places and other times where they would not seem to be decisions, but rather facts (MoL 1999), as will be shown in the following section.

The NAM competition also set out to deal with practical issues, such as the lack of space in the existing museum to exhibit recent archaeological findings and the need to shield the museum from pollution (KONTARATOS 2010; MPOURAS 2010).

The resulting realities of the four competitions are not related so much to choices about these two practical problems; they rather illustrate a concern to find the right system to support this reality. As STENGERS states, in order to become «true» something has to attract 
interest; it has to be relevant to, and intervene in, people's everyday lives (LAw 2004: 39). In other words, as the project of NAM entangled with the Parthenon marbles and attracted political interest in an international setting (YALOURI 2001), what was a practical challenge became a national issue and a way

«to shape a national identity by creating powerful bonds between the 〈progressive> past and the ongoing present» (FouseKI 2006: 534).

These are the political «inversions» that created a «forensic» architecture, an architecture of proofs. As the following jury comments of the first prize in 2001 illustrate, their arguments refer directly to the political discourses of the NAM: the

«restoration of the unity of the monument $[\ldots]$ in one place, and through the visual contact with the Parthenon temple» (GAZI 1990: 245)

«[...] the central conception [...] links the expectations of the international community for the reconstitution of the Parthenon sculptures» (OANMA 2001: 4)

«[...] the jury selected the proposal with strong central concept $[\ldots]$ which draw its power from the visual relation with Acropolis» (Kotsıopoulos 2010: 133).

Summing up, it can be said that the ways that the political, practical and social demands affected the actual decision and the creation of NAM, changed. In every competition, laws, judgement processes, protagonists and outcomes travel with different vehicles, localising in a totally unique way the global within the Makrigianni site.

Furthermore, every competition, as well as other contemporary events, such as the Olympic games, provided a tried-and-tested toolkit for processes in the Greek setting and «shifted the site of the decision elsewhere». As it is stated in the parliament discussion in 1999, one year before the fourth competition was announced:

«E. PAPAzor (Minister of Culture): [...] in contrast to the architectural competition of 1989 , now we are talking about «coherent» offices and not about architectural ideas, such as those in 1989 [...], firms with extensive experience will be required, $[\ldots]$, as it is defined by the known process of the European Union. [...] NAM will be ready in 2004» (Hellenic Parliament 1999).

\section{What is at stake? Negotiations and the quality of place making}

The aim of this paper is to locate the dynamic processes of the genesis of form of the NAM (like social movements, political narratives, socio-technical collectives and frameworks) in force fields of different tendencies and illustrate how by tracing these processes and tendencies we can achieve a better understanding of place making.
As stated above, the NAM assembled different facts and actors through a common platform of four competitions: global problems such as pollution and the need for a bigger museum to house new archaeological findings, gain importance and relevance by entering «assemblages» like the «national identity» and «international cultural heritage of the Acropolis marbles». Thus, the new museum not only protects and houses the endangered international cultural heritage but its qualities work as a proof of the restoration of Greece (YALOURI 2001: 47) and a restitution of its prestige (YALOURI 2001: 85).

The decision to construct a new museum requires in the first place a specific site that satisfies the practical issues (economic and technical), architectural values (in terms of the resulting relation with surroundings or the architectural relation with Acropolis) as well as being in line with political argumentation (e.g. return of the Parthenon marbles to their natural context (FousEKI 2006)). Secondly, specific decision-making tools, such as the competitions, to produce the plans for the NAM, are required.

According to VAN Wezemael and Loepfe (2009), a problem is staged by «singularities», a set of «main concerns» around which a variety of actualisations of one problem emerge. Singularities are modulated during the trajectory of changing a place from imaginary into reality (VAN WeZemael 2010b). For the NAM these singularities, highlighted in the two previous paragraphs, are brought together and negotiated in specific material and human contexts provided by the four competitions, and resulted in multiplicities of the NAM.

Following this perspective in view of gaining a better understanding of place making, this study not only traces the relations between these «singularities» but also explores them beyond the frame of the four competitions. More precisely, in the case of the NAM, political issues such as the interrelation of cultural, economic and political aspirations, the entrance into the EU and the arrival of the free market were what MASSEY (1999) calls «grand narratives». They «read» spatial differences of places within an overall story and thus shift the original focus from the creation of a new museum towards the different trajectories. This is problematic for three reasons. Firstly, as MASSEY (1999) argues, these grand narratives are «singular»; they suppress the «multiplicity» or «differences» of spatiality. Secondly, such narratives are not really open because the future is already inscribed in the stories they tell. Lastly, as a result, these grand narratives lead to an unstable gathering of elements that make up the NAM problem; a good reality is one that is centrally co-ordinated, meaning that the decisions somehow

«[...] sustain a strong perspectival and singular version [...] even as they manufacture multiple realities» (LAW 2004: 53). 
Judgements made on the basis of relations that are «spatially abstracted from power», relations viewed only through the prism of one narrative, cannot be coordinated since they have already been ordered in terms of hierarchy. Judgements are hastily made and do not take account of all the actors or their power. This can be illustrated by the cases of the two last competitions, which were distracted by the coalition of two big narratives (issues of identity and «return of the marbles») that shifted political argument to museological and even architectural ones.

In conclusion it may be said that understanding the dynamic processes of the genesis of form in place making implies a critical attitude towards «politics», as citizens, architects and planners: political decisions should take spatiality seriously and this means understanding spatiality and places as processes and as the products of interrelations. Places bring together different trajectories in space and time. Sometimes these can be aligned; sometimes they intersect. As MASSEY (1999) states, places can be disrupted and therefore not totally coherent. It is also important to consider time because it «automatically» results in processes with loose ends - not closed systems but open ones. These are not theoretical approaches but practical tools for place making because they do not permit normative answers and oppressive hierarchies. Instead, they enable an understanding of spatiality as «multiplicities», places where different narratives should be able to coexist and be enacted side by side.

\section{References}

Amin, A. (2004): Regions unbound: Towards a new politics of place. - In: Geografiska Annaler 86, 1: 33-44. Chupin, J.P. (2010): Analogie et théorie en architecture, de la vie, de la ville et de la conception, même. - Gollion: Infolio.

DeLANDA, M. (2002): Intensive science and virtual philosophy. - London: Continuum.

DeLAndA, M. (2006): A new philosophy of society. Assemblage theory and social complexity. - London, New York: Continuum.

DeLanda, M. (2010): Cities and nations. - In: Hillier, J. \& P. HeAley (eds): The Ashgate research companion to planning theory: Conceptual challenges for spatial planning. - Aldershot: Ashgate: 251-272.

DuBEY, J. (2005): Le concours en droit des marchés publics, la passation des marchés de conception, en particulier d'architecture et d'ingénierie. - Zurich: Schulthess. Dunne, J. \& H. Doetsch (2006): Raumtheorie: Grundlagentexte aus Philosophie und Kulturwissenschaften. - Frankfurt am Main: Suhrkamp.

Fouseki, K. (2006): Conflicting discourses on the construction of the New Acropolis Museum, past and present. - In: European Review of History/Revue européenne d'histoire 13, 4: 533-548.
GAZI, A. (1990): Museums and national cultural property II. The Parthenon Marbles. - In: Museum Management and Curatorship 9, 3:240-55.

HeAley, P. (2007): Urban complexity and spatial strategies: Towards a relational planning for our times. London: Routledge.

Hellenic Parliament (1999): Minutes of the session 15.11.1999. - http://www.hellenicparliament.gr/ 7.3.2011.

Hillier, J. (2010): Introduction to part two. - In: HiLlIER, J. \& P. Healey (eds): The Ashgate research companion to planning theory: Conceptual challenges for spatial planning. - Aldershot: Ashgate: 236-250.

IOS (2002): To neo Tama tou Ethnous. - In: Journal Kathimerini, 10.03.2002, Athens, http://www.iospress. gr/ios2002/ios20020310a.htm 7.3.2011.

Koноuteк, R. (2005): Der unmögliche Wettbewerb. In: Ö. G. f. Architektur (ed.): Wettbewerb! Competition! - Wien: ÖGFA: 124-129.

Kontaratos, S. (1978): The Acropolis Museum. - In: Architectonika themata. Architecture in Greece 12: 215-240.

Kontaratos, S. (2010): To adoxo terma enos dromou met' empodion. - In: Architectonika themata. Architecture in Greece 44:130-132.

Kotsiopoulos, A. (2010): The museum and the logic of its aesthetics. - In: Architectonika themata. Architecture in Greece 44: 133.

Kreiner, K. (2007): Strategic choices in unknowable worlds. Preparing for success in architectural competitions. - http:/www.clibyg.org/dyn/files/knowledge_ items/33-file/Kreiner.Strategic $\% 20$ Choices $\% 20$ in $\% 20$ Unknowable\%20Worlds.publish.pdf 28.10.2010.

LATOuR, B. (2005): Reassembling the social: an introduction to actor-network-theory. - New York: Oxford University Press.

LAw, J. (2004): After method: Mess in social science research. - New York: Routledge.

LAW, J. \& J. URRY (2004): Enacting the social. - In: Economy and Society 33, 3:390-410.

Massey, D. (1999): Spaces of politics. - In: Massey, D. Allen, J. \& P. SARre (eds): Human geography today.Oxford: Wiley-Blackwell: 279-294.

Ministry of Culture \& D.O.M.S. (1991): The New Acropolis Museum. - Athens: Ministry of Culture, Directorate of Museum Studies.

MoL, A. (1999): Ontological politics, a word and some questions. - In: LAw, J. \& J. Hassard (eds): Actor network theory and after.- Oxford:Wiley-Blackwell:74-89. Mpouras, C. (2010): A spacious and transparent museum. - In: Architectonika themata. Architecture in Greece 44: 136.

OANMA (2001): The competition of the New Acropolis Museum. - Athens: OANMA.

Paisiou, S., Van Wezemael, J.E. \& J.M. Silberberger (2011): Le jury et la «connaissance dans l'action». - In: ARQ 154: 44-47. 
Pangalos, T. \& L. Mendoni (2009): To chroniko tou neou Mouseiou tis Akropolis. - In: Kathimerini, 27228, 19.07.2009, Athens: 8 .

Thrift, N. (2000): Afterwords. - In: Environment and Planning D: Society and Space 18: 213-255.

VAN WEZEMAEL, J.E. (2010a): Urban governance and social complexity. - In: De Roo, G. \& E. DA Silva (eds): A planner's encounter with complexity. - Aldershot: Ashgate: 287-307.

VAN WeZEMAEL, J.E. (2010b): Modulation of singularities: a complexity approach to planning competitions. In: Hillier, J. \& P. HeAley (eds): The Ashgate research companion to planning theory: Conceptual challenges for spatial planning. - Aldershot: Ashgate: 273-289.

Van WezemaeL, J.E. \& M. Loepfe (2009): Veränderte Prozesse der Entscheidungsfindung in der Raumentwicklung. - In: Geographica Helvetica 64, 2: 106-118.

Van Wezemael, J.E., Silberberger, J.M. \& S. Paisiou (2011): The unfolding of the «good». - In: Scandinavian Journal of Management 27,1: 167-172.

VOLKer, L. (2010): Deciding about design quality, value judgements and decision making in the selection of architects by public clients under European tendering regulations. - Leiden: Sidestone.

YALouri, E. (2001): The Acropolis: global frame, local claim. - Oxford, New York: Berg.

\section{Legislation}

1. F.E.K (1970) E27960/1665/70. - http://www.et.gr/ 30 . 10.2010 .

2. F.E.K (1998) P.D.346. - http://www.et.gr/ 30.10 .2010 .

3. F.E.K (1994) - http://www.et.gr/ 30.10.2010.

4. F.E.K (2000) N2819/2000. - http://www.et.gr/ 30.10 . 2010.

5. EEC (1992): Council Directive 92/50/EEC. - http:// eur-lex.europa.eu/ 30.10.2010.

\section{Competition Documentation}

a. Jury report (1990): International competition for NAM, Minutes (Phases A, B).

b. OANMA (2000): Detail call for the preselection of contributors for the architectural, engineering and electromechanical study of the New Acropolis Museum.

c. Assessment Committee (2001): Minutes (Phase B). - Athens: OANMA.

\section{Summary: Four performances for the New Acropolis Museum. When the politics of space enter the becom- ing of place}

The study presented in this article is a trajectory of four competitions for the New Museum of Acropolis in Athens, studied as «inscription devices». This study illustrates that decisions about place making can be performed in many ways. It «opens the black boxes» of the four competitions in order to trace the landscape of possibilities that they introduce.

Keywords: architectural competitions, place making, assemblage theory, actor network theory

Résumé: Quatre projets pour le Nouveau Musée de l'Acropole (Athènes): politique de l'espace et devenir des lieux

Cet article présente une étude centrée sur quatre concours d'architecture pour le Nouveau Musée de l'Acropole à Athènes, étudiés comme des «dispositifs d'inscription». Cette étude illustre les multiples façons dont les décisions liées à la création des lieux peuvent être exécutées. Elle contribue à ouvrir la «boîte noire» de ces quatre concours, dans le but de montrer l'éventail des possibilités architecturales qu'ils peuvent introduire.

Mots-clés: concours d'architecture, création des lieux, théorie de l'agencement, théorie de l'acteur-réseau

\section{Zusammenfassung: Vier Projekte für das neue Akropolis-Museum. Wenn die Politik des Raums das Entstehen eines Ortes beeinflusst}

Dieser Artikel präsentiert eine Studie über vier Architekturwettbewerbe für das Neue Museum der Akropolis in Athen, insbesondere wie diese als Inskriptionsinstrumente funktionieren. Die Studie illustriert, dass Entscheidungen des «place making» auf viele Weisen durchgeführt werden können. Sie öffnet die «black boxes» der vier Wettbewerbe, um deren Möglichkeitslandschaften zu erkunden.

Schlüsselwörter:Architekturwettbewerbe, place making, Assemblage-Theorie, Akteur-Netzwerk-Theorie

Sofia Paisiou, $\mathrm{PhD}$ Candidate, University of Fribourg, Department of Geosciences, Geography Unit, Chemin du Musée 4, CH-1700 Fribourg, Switzerland. e-mail: sofia paisiou@unifr.ch

\section{Manuskripteingang/received/manuscrit reçu le 5.11.2010 \\ Annahme zum Druck, accepted for publication, accepté pour publication: 8.3 .2011}

